\title{
The Westerner: Matteo Ricci's World Map and the Quandaries of European Identity in the Late Ming Dynasty
}

\author{
Florin-Stefan Morar \\ Harvard University \\ morar@fas.harvard.edu
}

\begin{abstract}
Beginning with the late Ming dynasty, Europeans in China assumed the name of "people from the Great Western Ocean" (Daxiyang ren 大西洋人), often shortened to “Ocean people” (yang ren 洋人) or “Western people” (xi ren 西人). What is the origin of this name? This paper seeks to answer this question by suggesting a new interpretation of the cartography of Matteo Ricci. Much of the scholarly debate about the Ricci world map revolves around the notion that it was a scientific artifact meant to present an accurate image of the world to a willfully ignorant, but otherwise impressive civilization. This paper argues instead that the purpose of Ricci's cartographic project was to sustain a new identity, that of the Westerner and of the "Great West," notions created in translation by borrowing and modifying Ming China's geopolitical vocabulary.
\end{abstract}

\section{Keywords}

Ming dynasty - the West - Western identity in China - world maps - cartographic politics - Matteo Ricci - Kunyu wanguo quantu

In June 1616, the Minister of the Board of Rites in Nanjing, Shen Que (沈㴶, ?-1624), submitted a memorial to the Emperor Wanli of the Ming requesting the deportation of a number of foreigners, Europeans associated with the Jesuit 
order, on account of their spreading unorthodox ideas into China. ${ }^{1}$ Among the twelve points raised by Shen to justify the request, one is particularly striking. How could the foreigners call their country "Great Western Ocean?" asked the memorial in outrage. Under heaven and in all the known world, it further explains, there can be only one enlightened ruler - the Chinese emperor-and, as such, only the domain of his rule (the Ming) can truly be "Great." How could these barbarians dare "speak of two Greats, which are in mutual opposition?"2

The character used by Shen to mean "Great" is $d a$ (大), which originally meant "big," and the name for "Great Western Ocean" he took issue with is $d a$ xi yang (大西洋). As Timothy Brook has recently shown, using the character $d a$ in the names of states, such as in Da Ming (大明 “The Great Ming”), has an important history in East Asia. "Great state" (大國 da guo) is perhaps, as Brook suggests, one way of saying empire. The expression "Great Western Ocean," on the other hand, has so far failed to capture equal attention from scholars. Concepts of the Western Sea 西海 and even Western Ocean 西洋 (routinely without the prefix "Great" $d a$ 大) had been present on Chinese maps and in geographical texts to illustrate the Indian Ocean. But the Great Western Ocean first appeared on the world maps Matteo Ricci created in China in collaboration with various local scholars seemingly as a label for what we would call the Atlantic. ${ }^{4}$ But was the Great Western Ocean merely the Atlantic? Was Shen Que confused when he was assuming that it was used for the name of a guo (國), a country or state? Was he wrong when warning that the foreigners he was trying to deport created another "Great," which they opposed to the Ming?

Much of the scholarly debate about the Ricci world map revolves around the notion that it was a "scientific" artifact— that its purpose was to present an

1 This is one of three memorials submitted by Shen. A detailed study in Edward Thomas Kelly, "The Anti-Christian Persecution of 1616-1617 in Nanking" (PhD diss., Columbia University, 1971).

2 Andrew Chung, Mingmo qingchu yesuhui sixiang wenxian huibian [明末清初耶穌会思想文 献汇编] (Beijing: Beijing Daxue, 2003), 5:34 (henceforth abbreviated as MQYw).

3 Timothy Brook, “Great States," The Journal of Asian Studies 75, no. 4 (2016): 957-72.

4 A distinction between a Great and a Small Western Ocean appeared in one Yuan gazetteer (Nan hai zhi 南海志, 1304) as applied to different parts of the Indian Ocean, but an Eastern and a Western Ocean are also part of the Ptolemaic geographic tradition and was illustrated on a globe by the Tuscan artisan Matteo Neroni present in the Collegio Romano while Ricci was a student there. Nevertheless, when and where the name first appeared is less important. As this paper argues, the innovation in Ricci's world map was not limited to a new strategy for naming oceans, but in creating a new identity around the notion of the Great Western Ocean. On Chinese Oceanic naming practices see: Qiong Zhang, Making the New World Their Own: Chinese Encounters with Jesuit Science in the Age of Discovery (Leiden: Brill, 2015), 131-32. 
accurate image of the world to a willfully ignorant, but otherwise impressive civilization. ${ }^{5}$ The question specifically turns on whether, and how much, this artifact influenced China, especially in the narrow terms of the latitude and longitude system, with an important essay by Cordell Yee arguing that it did not do so. ${ }^{6}$ But was the purpose of Matteo Ricci's world map that of introducing scientific geography? Was the latitude and longitude grid its most important asset? The extant sources never mention that particular aspect of the map. Instead, Ricci's account of the entry of the Jesuit enterprise into China and his letters reveal that it was extensively used for three purposes: first, as an exotic gift to important officials; second, as a means of demonstrating the skills and knowledge (and ultimately usefulness) of the Jesuits; and third, for explaining in a succinct and compelling way who the Jesuits were, where they were from, and why they were worthy of attention and reverence. ${ }^{7}$ With respect to this last purpose, Ricci created a heretofore nonexistent identity-that of the Westerner - and a new notion - that of the "Great West" - a place fashioned into a counterpart of the Ming eighty thousand $l i$ away. ${ }^{8}$ Shen Que was, in fact, immensely perceptive about this aspect of Ricci's project of cartographic translation, pointing us towards a fresh interpretation of world maps by Ricci and, by extension, others based on it.

\section{The Pope of India}

Matteo Ricci was not the first missionary to enter China in the sixteenth century. Michele Ruggieri arrived earlier in 1579, and he did not come to China as

5 See for example the influential paper of Kenneth Ch'en, "Matteo Ricci's Contribution to, and Influence On, Geographical Knowledge in China," Journal of the American Oriental Society 59, no. 3 (September 1, 1939): 325-59. Similar ideas are present in various works by Pasquale D'Elia, notably Il mappamondo cinese del p. Matteo Ricci, S.I. (Vatican City: Biblioteca Apostolica Vaticana, 1938). The positivist take on Ricci's map was mainstream for several decades and still appears in various contributions.

6 Cordell D. K. Yee, "Traditional Chinese Cartography and the Myth of Westernization," Cartography in the Traditional East and Southeast Asian Societies (Chicago: University of Chicago Press, 1994), 170-202.

7 To my knowledge, only the the first point has been comprehensively treated in the literature. See Qiong Zhang, "Matteo Ricci's World Maps in Late Ming Discourse of Exotica," Horizons: Seoul Journal of Humanities 1, no. 2 (December 2010), 215-50.

8 On his world map Ricci calculated eighty thousand $l i$ by calculating the value of longitude degrees in $l i$. Later Jesuits however used the value ninety thousand $l i$, probably because it had a better stylistic resonance in Chinese. 
a "Westerner," nor even as a "European." As Willard J. Peterson has shown, soon after the Jesuits entered Canton and reached the city of Zhaoqing they dressed in Buddhist robes and, for this reason, were allowed to stay in the complex of a Buddhist temple. ${ }^{9}$ But the translation of the identity of the Jesuits was not only expressed in dress, but also in geographical ideas. Ruggieri produced the first draft of his catechism in Zhaoqing between October 25 and November 12, 1581. This translation was done together with two young Chinese in his service, to whom he dictated in Portuguese. ${ }^{10}$ The printed edition from 1584 is signed by Ruggieri with his Chinese name Luo Mingjian (羅明堅) and the specification tianzhuguoren (天竺國人, Tenjikujin in Japanese), which we would now translate as "a person from India."11 Why did Ruggieri use this geographic notion of Tianzhuguo as denominating his place of origin and that of his doctrine?

The expressions "person from India," or "people of India" were first used by the missionaries in Japan. Francis Xavier (1506-52) reported, as early as 1549, that the Japanese he encountered referred to his place of origin as Chengicu, Chynquinquo or Chingico, all, no doubt, European interpretations of Tenjiku. ${ }^{12}$ Xavier's and other accounts suggest that their appellation also came with the understanding that the Jesuits were practicing an especially zealous form of Buddhism.

Undoubtedly, Jesuits profited greatly from the association with Buddhism. ${ }^{13}$ It helps explain the early popularity of Christianity in Japan as a kind of Buddhist revival and the material benefits obtained by the missionaries. This, however, placed the Jesuits in the position of performing a delicate act of double

Willard J. Peterson, "What to Wear? Observation and Participation by Jesuit Missionaries in Late Ming Society," in Implicit Understanding: Observing, Reporting, and Reflecting on the Encounters between Europeans and Other Peoples in the Early Modern Era, ed. Stuart Schwartz (Cambridge: Cambridge University Press, 1994).

10 See Pasquale M. D’Elia, “Quadro storico sinologico del primo libro di Dottrina cristiana in cinese," AHSI 3 (1934): 193-222.

11 ARSI, Jap. Sin. II, 189.

12 A relevant passage in Franciscus and Alessandro Valignano, Monumenta Xaveriana (Madrid: Typis Augustini Avrial, 1899), 1:488. To a modern reader, it is clear from Xavier's summary of the views of his informants that Chenjico is India, described as a country beyond China and Tartary, yet it did not appear to have rung any bells with Xavier and his companions, at least not explicitly.

13 There is disagreement among historians to the extent to which the Jesuits were misleading. See Hans Haas, Geschichte des Christentums in Japan (Tokyo: Rikkyo Gakuin Press, 1904) and Georg Schurhammer, Francis Xavier: His Life, His Times (Rome: Jesuit Historical Institute, 1982). Cf. the series of articles by Urs App, "Xavier's Discovery of Eastern Buddhism," The Eastern Buddhist 30, no. 1 (1997): 53-79, 30, no. 2 (1997): 214-44 and 31, no. 1 (1998): 40-71. 
translation. Even as they adapted the language of Buddhism to the necessity of communicating a radically different doctrine, they presented their progress back in Europe as purely motivated by the supposed thirst the Japanese had for the Christian message, cancelling out all references to Buddhism. A case in point is the translation of the first document in Chinese characters in Europe, advertised as the donation of a "church," by the "Duke" of Yamaguchi. ${ }^{14}$ The Japanese text states in fact that a donation is given to Buddhist monks seng (僧) from the "Western regions" (Xiyu, 西域), in Japanese literature and cartography a reference to the origin of Buddhism, so that they could promulgate the Buddha Dharma on the grounds of the Daidao Temple of Yamaguchi. The Portuguese translation of this text states instead that the purpose is to "preach the law that makes saints" (que vierão declarar lei de fazer Santos) and "temple and community" (寺家) is rendered in Portuguese only as esta or "this."15

The translation of Tenjiku back to European languages followed the same pattern. Xavier never explained in his letters what Chenjico meant, implying it was a word for Europe. Historians of the mission followed suit, drawing the connection explicitly. Emanuel Acosta (d. 1604), for example, wrote: "Cengecu (sic enim Europaeos appellant)" [Cengecu, as the Europeans call it]. ${ }^{16}$ Others, with knowledge of Japanese, explained the word literally: "chengico here meant thing that came from heaven," suggesting implicitly to their home audience that the Japanese thought, that the Jesuits were heaven sent. ${ }^{17}$ (The two characters 天筀 had been used to refer to India as the source of Buddhism since the Tang dynasty but literally meant "heavenly bamboo.")

The Indian identity, and the act of double translation it implied, followed the Jesuits into China. Michele Ruggieri's account with the title Relatione del

14 Cartas que os padres e irmãos da Companhia de Jesus escreverão dos reynos de Japao \& China (Manoel de Lyra: Evora, 1598), Tom. I, 61.

15 Various versions of the document presented in Georg Schurhammer, Das kirchliche Sprachproblem in der Japanischen Jesuitenmission des 16. und 17. Jahrhunderts (Tokyo: Deutsche Gesellschaft für Natur- und Völkerkunde Ostasiens, 1928), 76-77. See also Haas, Geschichte des Christentums, 2:58-6o and App, "Xavier's discovery of Eastern Buddhism," 237. There is debate among scholars of the Japanese mission about whether this translation was part of a "pious ruse and cover up," or simply ignorance.

16 Emanuel Acosta, Rerum a Societate Iesu in Oriente gestarum (Dillingen an der Donau: Sebaldus Mayer, 1571), 78 .

17 As cited in Juan Alfonso de Polanco, Vita Ignatii Loiolae et rerum Societatis Jesu historia (Madrid: Typis Augustini Avrial, 1895), 3:493: "quidquid Patres e chengico venientes dicerent, mendacium esse affirmabant; chengicum ipsi rem e coelo venientem interpretantur." ["It is not true that the fathers said they came from chengico; chengico here meant thing that came from heaven."] cf. D’Elia, Quadro storico-sinologico, 214. 
successo della missione della Cina (Account of the success of the mission to China), which remains in manuscript at the Jesuit archives in Rome, offers important details in this regard that were left out of Ricci's widely disseminated published account. ${ }^{18}$ In two instances, Ruggieri describes the usage of the word Tien cio cuo, his phonetization for tianzhuguo (天竺國). During a trip up the coast to Zhejiang province, Ruggieri writes of being in front of a large crowd when "the governor asked me in anger: where are you from?" "I replied," writes Ruggieri, "I am a person from Tien cio cuo." ${ }^{19} \mathrm{He}$ explains in translation that, "I told him, we are from that Kingdom, which they call of heaven." ${ }^{20}$ Yet, in another place in his account, Ruggieri gives another interpretation of "Tien cio cuo" when he recounts the Visitor Alessandro Valignano's (1539-16o6, visitor from 1578) response to the proposal of sending an embassy to Beijing to gain permission for the Jesuits to settle in China. Valignano considered a new embassy, under the aegis of the newly unified Iberian monarchy impossible "because the Chinese have a prophecy that says that they will lose their kingdom every time a new embassy was admitted and this is known by their King and the Viceroys." ${ }^{21}$ For this reason, according to Ruggieri, Valignano proposed that the embassy be made instead under the name of the "Kingdom of Tiencio'cuo," because "the embassy from this kingdom was ancient, as it was seen in the Chinese books."22 Tiencio'cuo was here a kingdom on Earth, not in heaven, a meaning reflected in a draft papal letter composed by Ricci in support of Ruggieri's embassy. The letter was drafted in the name of Sixtus V (r.1585-89) whose name was rendered phonetically by placing a kou $\square$ mouth radical in the composition of three characters: $\square$ 西瑡口都 (Xishidu) and was presented in Chinese, in a literal reading, as the Bonze Emperor (seng huang 僧皇) of the Capital of the Great Sect of the Lord of Heaven (Taiseng tianzhujiaomendu senghuang 太僧天主教門都僧皇), who resided in the capital of Tianzhu Tianzhuguo jingshi (天笂國京師). ${ }^{23}$ Tianzhuguo is also presented in the letter as the place of origin of the doctrine of the Lord of Heaven. Important for the practice of double translation is the Latin version of the Chinese ambassadorial letter, which still exists in the Roman Jesuit Archives. This version

18 ARSI, Jap. Sin. 101.

19 “il gouernatore et gli dima'dò co' fiero uolto Na li gin...gli rispose ieie Tien cio cuo sen.”

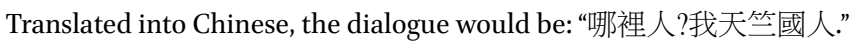

20 ARSI, Jap. Sin 101, fol. 92-94. "S. re io sono di ql Regno che loro chiamano del cielo."

21 ARSI, Jap. Sin. 101, f. $5^{2^{r} \text {. }}$

22 ARSI, Jap. Sin. 101, f. $5^{2^{\mathrm{v}}}$.

23 We know that the letter was by Ricci, based on Valignano's account in the letter from November 21, 1588. ARSI Jap. Sin. 11-1, fol. $13^{\mathrm{v}}$. 
suggests another meaning given to Tianzhuguo, different from that presented by Valignano. ${ }^{24}$ Here it is rendered twice in the text as "Tien-La" and explained as a place translation for the Vatican: "nos hic regnum tenentes in Tien La (i.e. coelestis palei) territorio." The dating portion at the end of the letter describes it as "Datum in Urbe Regio (i.e. Romae) Tien-La territori." 25

Ricci's Chinese version of the letter and its Latin translation were taken by Ruggieri to Europe and engraved there in 1590. But by the time Ruggieri reached Rome, Sixtus V had died in August 1590. Gregory XIV (r.1590-91), who met Ruggieri in 1591, showed less interest and delegated the matter to the Cardinal Giovanni Fachinetti (1519-91, the future Innocent IX, October 29 to December 30, 1591), who handled the diplomatic affairs of the Holy See. The cardinal seemed pleased, at least according to Ruggieri, by the translations in the letter, but the matter never made it further and Ruggieri was retired to Salerno, where he died in 1606.

In his published account of the entry into China, Ricci does mention the drafting of the papal letter and the embassy project, but doesn't give any details about how the letter was written, mentioning only that is was done "according to the style of Chinese." The significant fact that the embassy was framed as coming from the kingdom of "Tienciocuo" is completely left out. In fact, besides a brief passage, in which Ricci mentions that the missionaries had to change clothing and adopt Buddhist robes, there is no reference to the larger project, with Japanese connections, to frame Christianity around Buddhism. ${ }^{26}$

24 The Chinese version of the letter was found in the BNF Chinois 1320 (together with woodblock) and was published first by Henri Cordier in L'imprimerie sino-européenne en Chine: Bibliographie des ouvrages publiés en Chine par les européens au XVIIe et au XVIIIe siècle, 5e sér., 3 (Paris: E. Leroux, 1901). It had been sent to Paris from Rome by Edouard de Malijay in 1878. Misled by the usage of Tianzhuguo, Cordier wrongly believed the letter was composed in Goa. Pietro Tacchi Venturi republished the letter in Matteo Ricci, Opere storiche del P. Matteo Ricci, S.I. (Macerata: Premiato stab. tip. F. Giorgetti, 1911), 2:493-95. Tacchi Venturi did not reproduce the original Latin translation of the letter, which he did not seem to know about. Instead, he published in Italian a new translation of a text by the Sinologist Léon Wieger. D'Elia does not mention the latin translation neither in his essay on Ruggieri's catechism, nor in Fonti Ricciane. Cf. D'Elia, Quadro storico-sinologico, 209-18; Matteo Ricci, Fonti Ricciane (Rome: Libreria dello Stato, 1985), 1:249. (henceforth abbreviated as FR).

25 ARSI Jap. Sin, 125 , fols. $68^{r}-68^{\text {v }}$. The letter is followed by a manuscript in Latin by Ruggieri entitled "159o Brevis de regno Sinarum comentaribus per P. Michelem Rugerium" fols. $69^{\mathrm{v}}-72^{\mathrm{v}}$. Valignano's letter from November 10 suggests that the translation was made by Duarte de Sande, a fact that discloses the disagreement between the Jesuits on key terms at this stage.

$26 \quad$ FR, 1:249. 
In the context of writing about the papal letter Ricci suggests that Ruggieri returned to Rome because he was no longer able to learn Chinese on account of his old age. ${ }^{27}$ Valignano's letters to the superior general in 1588 repeat the same argument. ${ }^{28}$ These arguments were used to prevent both Ruggieri's return to China and his project to publish a first translation of the Confucian Four Books in Europe. Significantly, on the title page of the relation Ruggieri composed in his defense, someone has added the comment, "One cannot trust this, period. In many relations the false is four quarters of the truth." 29

Ricci and Ruggieri's disagreements were about translation, identity and the usage of geographical knowledge. Ruggieri's perspective was, in a sense, Xavierian. He was in favor of couching the Christianity in the language of Buddhism and for the Jesuits to adopt the identity of "Indians," that is, people of Tianzhuguo. He was also explicitly against the usage of maps and geographical knowledge, writing in his account, "It is necessary that the fathers do not reveal to the Chinese that they know about the geographical descriptions of other countries and climes of provinces and lands because they will become suspicious that with this art they will harm this kingdom. There was one time when Ricci said to the Lingxidao (嶺西道, Wang Pan's official title) that he knew the measurements in latitude degrees of the location of Beijing and [Wang Pan] reprimanded him for saying that he knew such things." ${ }^{30}$ After Ricci was given free rein over the China mission and could implement his own program, he rejected Ruggieri's use of the vocabulary of Buddhism and its "Indian" identity while supporting, against Ruggieri's will, the use of maps and geographical knowledge in his contacts with Chinese scholars. He also broke with the Xavierian foundations of the mission in Japan, and Ruggieri's idea of carrying these strategies over to China. The failure of the Xavier-Ruggieri program to take hold in China was thus a political and religious decision, ideological rather than a response to events in China itself.

\section{The Road to Greatness}

If Ricci could not be a man from "India," like Ruggieri wanted to be, what could he become instead? In Asia, the Portuguese generally were referred to as "the

\footnotetext{
$27 \quad$ FR, 1:150.

28 ARSI, Jap. Sin. 11, $29^{\mathrm{v}}$.

29 ARSI, Jap. Sin. 101, 2 ${ }^{\mathrm{r}}$. "Non è da fidarsene punto. Che est falso v'è a tre quarti del vero in molte narrationi."

30 ARSI, Jap-Sin. 101, $110^{\mathrm{v}}$.
} 
Franks." The Jesuit mission was under the Portuguese patronage, but Ricci did not want to become a "Frank." As he wrote in his diary, this was a name given by Muslims, who still retained a memory of the crusaders when they again encountered Europeans in India and China. ${ }^{31}$ Ricci also believed that rumors started by the same Muslims in Guangzhou about the crude and cruel nature of "the Franks" were to blame for the difficulties of obtaining permission to enter China. ${ }^{32}$ The earliest editions of Ricci's world map contained in Chinese the location Fulangji 拂朗機 at the Western tip of Europe, roughly in the location of Portugal. ${ }^{33}$ The first printing of the 1602 edition added a small cartouche with the explanation: "the name Fulangji has been erroneously given by Muslims (huihui 回回). The real name is Portugal (Boerduheer 波尔杜曷 尔)"34 (Figure 1.1). In later versions of this 1602 edition, however, the text of the box was scraped off the woodblocks and Fulangji was replaced with a revised phonetic rendering for the name of Portugal (Boerdowaer 波爾杜瓦爾). With this, the Frankish identity of Europeans in China was wiped off the face of the world map. ${ }^{35}$

31 See Sanjay Subrahmanyam, Explorations in Connected History: Mughals and Franks (Delhi: Oxford University Press, 2005). FR, 1:151.

33 This label is present in the 1601 copy of Ricci's world map Shanhai yudi quantu [山海 輿地全圖] reprinted in Feng Yingjing [馮應京], Yueling guangyi [月令廣義] (1602). See Figure 1.2.

“拂朗機乃回回誤稱本名波尔杜曷尔." Kunyu wanguo quantu [坤輿萬國全圖] (Beijing: 1602), scroll 5 from right.

Cf. Unno Kazutaka, "Various editions of Matteo Ricci's K'un-yu-wan-kuo-ch'uan-t'u map," Tōhō Gakuhō, 87, no. 1 (2005), 101-43. Also Aoyama Hirō "The Impact of Ricci's World Maps on the Edo period of Japan," in La Cartografia di Matteo Ricci, ed. Filippo Mignini (Rome: Istituto Poligrafico, 2013), 121-37. Kazutaka compared the Japanese copies of the Ricci map with the Vatican, Library of Philip Robinson and Vienna versions. Kazutaka proposed that the Miyagi prefecture copy of the map was based on an early print of the map. A significant difference is found in the name for Portugal, rendered originally as Fulangji 拂朗機. This can be confirmed by examining the Nanjing palace copy of the Map, which we know was done by eunuchs in the palace out of Ricci's control and based on an early, unedited copy. This version also contains the place name 拂朗機, but without explanatory cartouche. The 1603 eight panel version of Ricci's world map made by Li Yingshi replaced this name with 波尔杜曷尔, but the explanatory reminds the earlier name reading: “The Muslims call this place Fulanji” (即回回所稱拂朗機). (Soongsil Christian Museum, Liang yi xuan lan tu 兩儀玄覽圖). The Vatican, Ambrosiana and James Ford Bell copies all show the signs of woodblock tampering, consistent with the deletion and replacement of 拂朗機. 

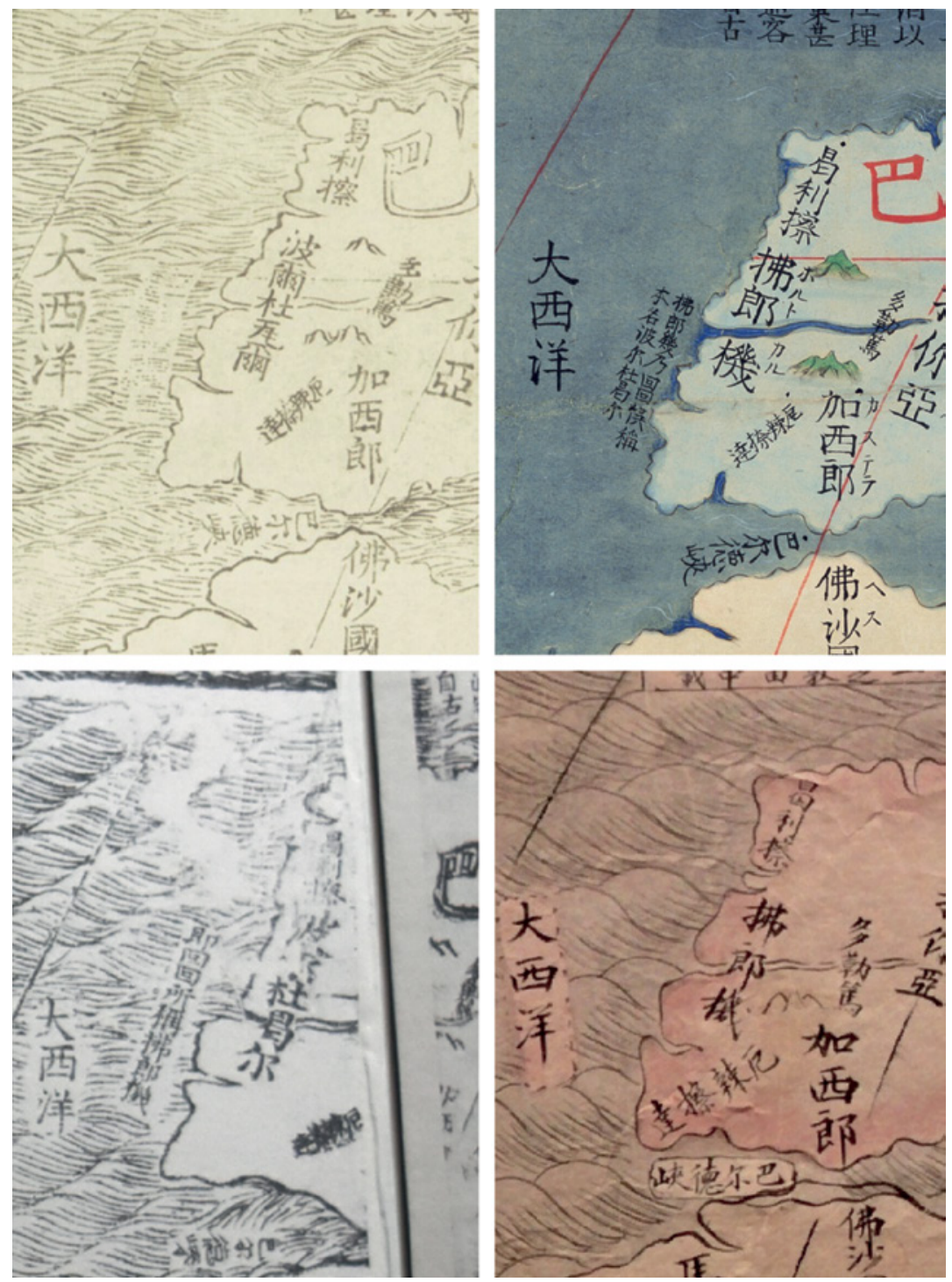

FIGURE 1.1 Matteo Ricci, Li Zhizao and Zhang Wentao, different versions of Kunyu Wanguo Quantu [坤輿萬國全圖]. Clockwise from top left: (a) James Ford Bell Library Minnesota altered 1602 version. Name of Portugal appears as Boerduwaer, explanatory notes show marks of deletion from woodblocks. (b) Miyagi prefecture modified original version, before tampering. Portugal appears as Fulangji, explanatory note intact. (c) Soongsil Christian Museum Korea, Liangyi Xuanlantu (photograph Florin-Stefan Morar). Portugal rendered as Boerduheer, label modified to reflect the name given by Moslems as Fulangji. (d) Nanjing Palace Museum (photograph Florin-Stefan Morar), colored 1608 version produced in the Beijing palace based on unadulterated original print. Portugal appears here as Fulanji, without other explanatory notes. 


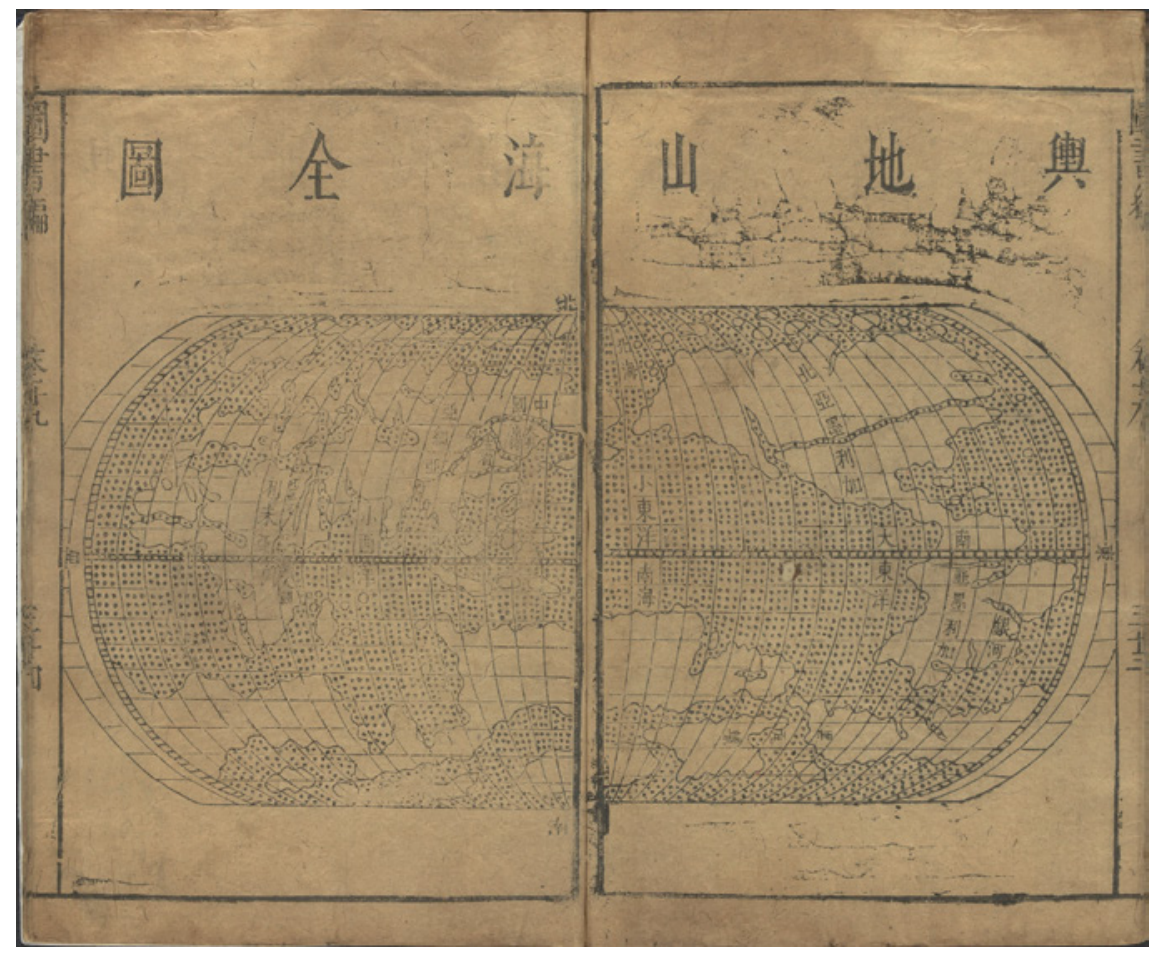

FIGURE 1.2

“Yudi shanhai quantu” [輿地山海全圖] in Zhang Huang, Tushubian [圖書編] (1613). Courtesy of Yenching Library Harvard University. This reproduction of Matteo Ricci's 1584 world map names all the continents except Europe. The Western Ocean (大西洋) is also absent.

Was Ricci attempting to construct an alternative identity to Indians and Franks before Ruggieri left for Europe? Ricci's courtesy name, his hao (號), chosen as early as 1585 , was Xitai (西泰) which combines “west" with a character designating a host of positive attributes, but also meaning "far" and "extreme."36 In a literal translation this name would thus be "one who is from

$3^{6} \quad$ It is unclear when Ricci obtained this name. The first historian of the Jesuit mission to China, Daniello Bartoli, assumes that this happened immediately after the entry to Zhaoqing in 1583 , but he cites no documents. He reports that the Visitor Valignano opposed their adoption because he feared rumors that the Jesuits abandoned their Christian names. Daniello Bartoli, Opere del padre Daniello Bartoli (Turin: Giacinto Marietti, 1825) 18:25-27. Cf. FR, 1:227 where Ricci mentions the adoptions of names. In a letter from 1588 Valignano defends the practice instead. See ARSI Jap. Sin. 10 II, $337^{\mathrm{v}}$. The first mention by Ricci of his own courtesy name as Xitai (西泰) occurs only much later, from 1599, in his Nanjing period. FR, 2:104. 
the far west." We know little about when Ricci adopted the name, as Visitor Valignano seemed to have initially opposed its usage. Nevertheless, if it indeed stemmed from the period when Ricci and Ruggieri were still at Zhaoqing, it might have been related to the inscription reported by Ruggieri on the door of the first Jesuit church at Zhaoqing which read xilai jingshi (西來淨士). ${ }^{37}$ Ruggieri translated this to his superiors as having the meaning "the fathers are most candid people, who came from the West," but to Ming readers it would have likely meant "saintly persons who came from India." In Ming understanding, after all, India was the west. Ricci's name Xitai 西泰 was therefore associated with the Jesuits' initial Buddhist identity.

Having opposed Ruggieri's vision, Ricci's initial program consisted in doing away with the discrepancies in translation, between the meanings reported to superiors in Europe and what the local Chinese understood by these identity markers. Around 1595, Ricci more explicitly started to designate a new place of origin for himself: "the Far West" (taixi 太西), which implied a distinction from an undefined "Near West." The first time such a usage appears is in the manuscript of the Treaty on Friendship signed "Matteo Ricci, Sagely Hermit from the Far West" Taixiguo shanren Li Madou (太西國山人利瑪竇). ${ }^{38}$ In the preface, Ricci writes that he came to China from the "Far West" (zi taixi ru hua 自太西 入華), referring once to a “Far Western homeland” (taixibang 太西邦). Then, in the print edition published between 1599 and 1601 in Nanjing, Ricci styled himself instead as "the European Matteo Ricci” (Ouluoba ren Limadou 歐羅巴 人利瑪犢). .9

For Ricci to have called himself "European" was highly unusual, both for his Chinese audience and in Europe itself, more comfortable with the broader concept of Christendom. In using this label, Ricci made Europe into something unrecognizable at the time, a unified cultural and political entity. As a cartouche on Ricci's 1602 world map informs us, in Ricci's Europe there was no room for the Reformation nor for the wars and divisions between various kingdoms, everybody was practicing the religion of the Lord of Heaven and

37 ARSI, Jap. Sin. 9, I, $264^{\mathrm{r}}$. The translation given by Ruggieri is "di occidente ci venero Padri homini candidissimi."

38 British Library Add. Mss. 8303. For modern critical editions see Matteo Ricci, Dell'amicizia, ed. Filippo Mignini (Macerata: Quodlibet, 2005) and On Friendship: One Hundred Maxims for a Chinese Prince, ed. Timothy Billings (New York: Columbia University Press, 2009).

39 The first printed editions we have are Biblioteca Apostolica Vaticana (BAV), Borg. Cin. 512 (4), Borg. Cin. 324(10), R.G. Oriente III 223 (9). The "European Matteo Ricci" also appears in prefaces on versions of his 1602 world map, but these texts might have been written at an earlier date, perhaps coinciding with the edition of the Treaty on Friendship. It's significant that a new preface which only appears on the 1603 edition is signed differently as the Jesuit Matteo Ricci (Yesuhuizhongren Li Madou. 耶穌會中人利瑪竇). 
the religious were also the highest magistrates, responsible for governing the whole of Europe. ${ }^{40}$ Nevertheless, "Europe" did not seem to quite have the right resonance in China. Zhang Huang 章㣴 (1527-1608), who reproduced a version of Ricci's world map in his 1613 cartographic collection Tushu bian (圖書 編) paid attention to it as a place of origin for people of Ricci's ilk, but chose to hear this word as Huluoba (胡洛巴) (Figure 1.3). Here, the character for hu (胡) referred to people living in ancient times north and west of China, coming to mean something like "exotic" when referring to some foods, musical instruments, and utensils. It was, in essence, a more cultured, but still obvious way of saying barbarian. ${ }^{41}$

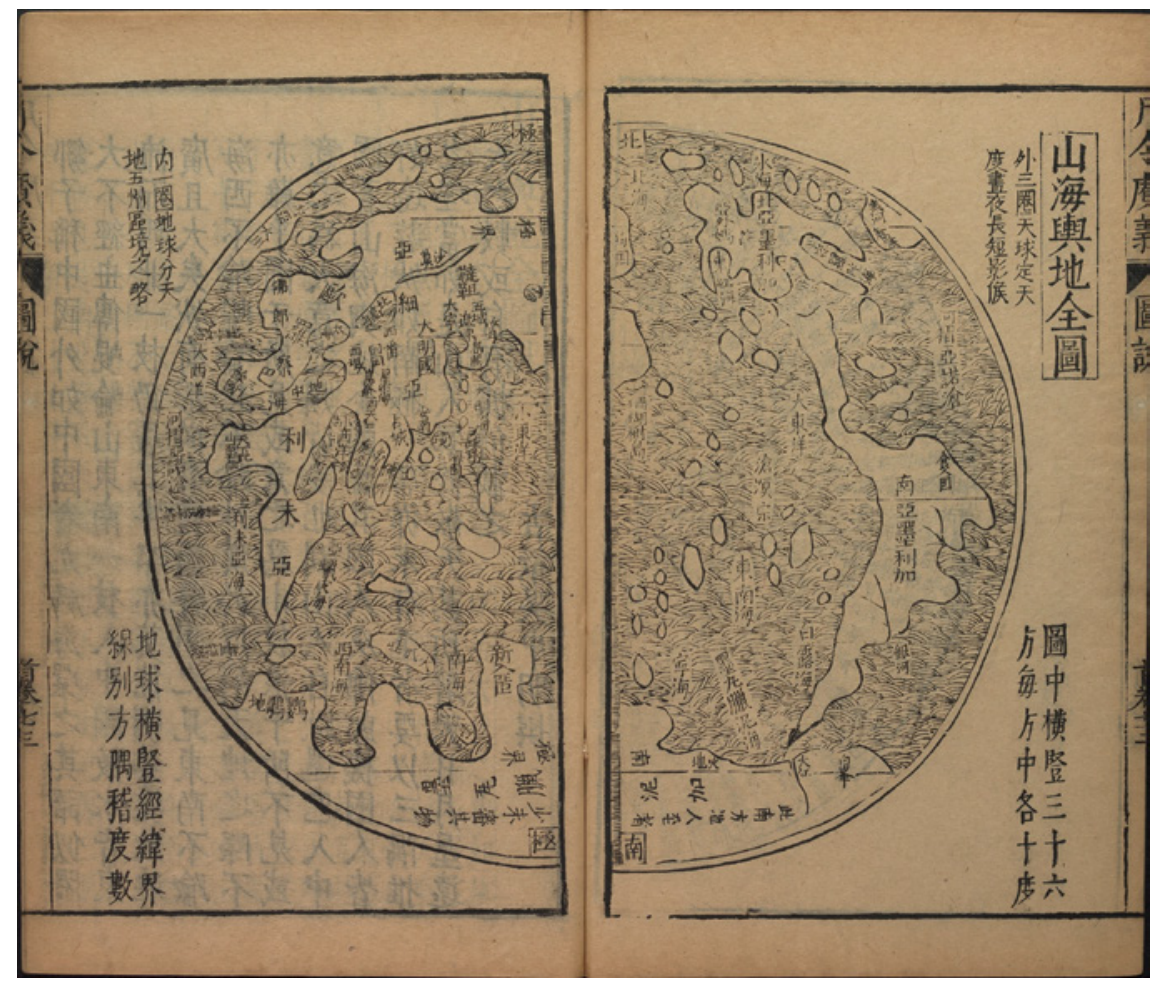

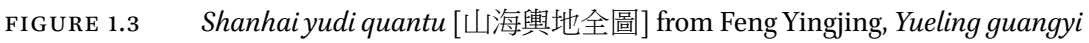
[月令廣義] (1602). This reproduction of the 1600 Nanjing version of Ricci's world map is the first to list the name of Europe and the Western Ocean. The map was later widely disseminated as part of the popular Ming encyclopedia Sancai Tuhui [三才圖會] (1609).

COURTESY OF YENCHING LIBRARY, HARVARD UNIVERSITY

40 Kunyu wanguo quantu [坤輿萬國全圖] (BAv Barb.Or.15o), scroll 5 from right.

41 Zhang Huang, Tushu bian 圖書編 (1613), 28:63-65. 
Perhaps for such reasons, the Nanjing edition of the Treaty on Friendship inaugurated yet another identity for Ricci. A 1599 preface written by Qu Rukui (篗汝熟, 1549-1611) is entitled "Preface for the Treaty on Friendship by Ricci from the Great Western Regions" Daxiyu Li gong youlun xu (大西域利公友論 序). ${ }^{42}$ The same Great Western Regions appear in the body of the text when narrating a maxim on friendship by Alexander the Great, presented as "ancient absolute monarch of the Great Western Regions" (Lishan Daxiyu gu zongwang 歷山大西域古總王). ${ }^{43}$ This preface thus marks the first usage of “Great," applied as a modifier, of "Western Regions," which in the Ming geographical imagination referred to spaces inhabited by Muslims, extending over land up to Persia and what we now term the Middle East. ${ }^{44}$ Interestingly, Qu Rukui placed the first character ( $d a$ 大) of both Great Ming and Great Western Regions one space above the line, a textual arrangement traditionally reserved for honoring names of emperors and concepts like heaven, suggesting a symmetry and a parallelism between the two. ${ }^{45}$

The preface represented an idea of cultural parallelism that Ricci fully embraced. Ricci constructed his own catechism, The True Meaning of the Lord of Heaven (Tianzhu shiyi 天主實義), as a conversation between a Western (西 士) and Chinese gentleman (中士, zhong or "middle") and even referred a few times in the text the words of a xi ru (西儒), a Western Confucian scholar. ${ }^{46}$ Moreover, in conversations with his collaborator Xu Guangqi (徐光啓) Ricci proposed that Europeans practiced forms of knowledge which had been present in ancient China, but then forgotten ${ }^{47}$ Temporarily, he also embraced the identity of a man from the "Great Western Regions." At least some editions of the Treaty of Friendship circulating in the Ming were signed with "Matteo Ricci, Sagely Hermit from the Great Western Regions" (大西域山人利瑪竇). 48 But Ricci later replaced Western Regions with another concept, that of the Western Ocean. In a later edition of the Treaty on Friendship, likely printed in 1601, Ricci became: "Matteo Ricci of the Society of Jesus, from the Great

\footnotetext{
42 BAV Borg. Cin. 512 (4), 6-8.

43 BAV, Borg. Cin. 512 (4), 28.

44 See Hyunhee Park, Mapping the Chinese and Islamic Worlds: Cross-Cultural Exchange in Pre-Modern Asia (New York: Cambridge University Press, 2012).

45 BAV, Borg. Cin. $512(4), 6$.

46 MQYW, 99.

47 See for example Xu Guangqi's Preface to Euclid's Elements 刻《幾何原本》序 in Li Zhizao, ed., Tian xue chu han, Zhongguo shi xue cong shu, 23 (Taibei: Taiwan xue sheng shu ju, 1965).

48 This appears in a copy republished as part of the collectanea Chen Jiru (陳繼儒), Baoyantangbij [寶顏堂秘笈] (1615).
} 
Western Ocean." (大西洋耶穌會士利瑪竇). The text was also systematically corrected to reflect this new concept, and Alexander the Great now became ruler of the Great Western Ocean (大西洋古總王). Moreover, Ricci's signature at the end of the book, which originally differed from "Great Western Ocean," was scratched off the woodblocks.

Ricci's identity seems to have stabilized around the idea that he was a person from the "Great Western Ocean" during his sojourn in Beijing in 1601. This was the way Ricci presented himself to the emperor Wanli on January 27, 1601. The memorial's author identified as a "Humble vassal from the Great Western Ocean” (Daxiyang peichen Li Madou 大西洋陪臣利瑪竇). In the body of the memorial, Ricci referred to the Great Western Ocean as "my country" (ben guo 本國), using it as a kind of brand for the various gifts offered as tribute: a musical instrument of the Great Western Ocean (大西洋琴), belts from the Great Western Ocean (大西洋各色腰帶), cloth and hemp cloth from the Great Western Ocean (大西洋布與葛布). 49

These transformations in identity can be traced in Ricci's world maps. The first edition of Ricci's world map, produced in 1584, which survives in the reproduction of Zhang Huang, does not have the expression Great Western Ocean on it, or for that matter any reference to Europe. ${ }^{50}$ But in the second edition, produced in 1600 and reproduced by Ricci's friend Feng Yingjing 馮應 京, 1555-1601 in Yue ling guang yi (月令廣義), the Great Western Ocean suddenly appears at what is now the western tip of Europe, which also makes an appearance as Ouluoba (歐羅巴). The Small Eastern Ocean is complemented by a Small Western Ocean, which is now placed near India, which is rendered correctly as Tianzhuguo (天竺國).

Though Ricci's world maps are a hybridization of Chinese and Western sources, the name of the oceans is a feature which doesn't have any direct corresponded in these sources. To be sure, the Atlantic Ocean, in accordance to Ptolemaic tradition, was also named "Oceanus Occidentalis," as in a terrestrial globe by the Tuscan artisan Matteo Neroni present in the Collegio Romano from 1574, which influenced Ricci's cartography. But in Ricci's work this plays another role, being part of a system of smaller and greater seas, which reflect not only the westward distance from the Ming - as Europeans distinguished for example between Asia Minor or Asia Major, but also its relative importance. Ricci was perfectly aware that "Great" had political valances. In his diary,

\footnotetext{
49 上大明皇帝貢獻土物奏 in MQYW, 282-84.

50 We only have "Small Eastern Ocean” (小東洋), “Great Western Ocean” (大東洋), “the Southern Sea” (南海), and “Small Western Ocean” (小西洋). Zhang Huang, Tushu bian [圖書編] (1613), 29, 33b-34a.
} 
he writes that in names of China used in Europe, people have added the word "Grande" or "Gran" as a debt paid to the greatness of its name and also to represent an idea of political and cultural unity, "it is as if four or five kingdoms are made one." ${ }^{51}$ As Ricci wrote, one of the key functions of his world map was, "to diminish the Chinese idea that their Empire embraced the whole world, whereas in this map it was just another, and not the largest, stretch of earth on the globe." ${ }^{52}$ As China became smaller, the "West" could become greater, which Ricci's 1602 map represented in a literal visual rendition by distorting the relative size of the two world regions. ${ }^{53}$ Regardless of Chinese opinions about the accuracy of the world map and the ways it inspired or did not inspire Chinese cartographers, "the Great Western Ocean" remained its most influential feature and formed a lasting legacy. All the Jesuits after Ricci called themselves people from the Great Western Ocean (大西洋人) and this label, shortened to "ocean people" (yang ren 洋人) or “Western people" xiren (西人) came to be applied in the next four centuries to all Europeans and later Americans in China.

\section{Conclusion}

In 1905, the Commercial Press in Shanghai published a new map of the Qing empire with the title Complete Map of the Great Qing Empire (Daqing diguo quan tu 大清帝國全圖). ${ }^{54}$ The Chinese cartographers involved represented the Qing by using a combination of Chinese and Western techniques. The maps feature latitude and longitude coordinates, borders, dotted lines and other symbols inspired from European maps. But the most interesting aspect of this collection is the title itself, which announces that the Great Qing is an "Empire"-a di guo (帝國). As Mark C. Elliott has shown, the usage of this word marked a return in Chinese translation of a concept under which China had been represented in Europe since the seventeenth century. ${ }^{55}$ It was also the first of such concepts. In the twentieth century, China became a "Republic" (Minguo 民國) and later a "People's Republic" (Renmin gongheguo 人民

\footnotetext{
$51 \quad$ FR, 1:10-11.

$5^{2} \quad \mathrm{FR}, 2: 474$.

53 This is one of the most significant distortions on the map relative to contemporary European maps. The size of the European subcontinent is enlarged to approximately twice the size of Ortelius 1570 map for example.

54 Da Qing diguo quantu [大清帝国全图] (Shanghai: Commercial Press 1905).

55 Mark C. Elliott, "Was China an Empire?" First JEsho Lecture on Asian History, Austrian Academy of Sciences, October 13, 2015.
} 
共和國). The outward appearance of Chinese states was thus vested in translated Western notions. But as the origins of the term in Ricci's search for a geographical identity in China show, the very notion of the West was created in a reverse process, a translation of identity based on a Chinese worldview. Ricci's fashioning of the West was initially driven by the necessity to reconcile the meaning gap between what the West originally meant in China and how it was translated in Europe, a result of the peculiar strategies of Michele Ruggieri. Ricci wanted to shift the meaning of "the West" in China to mean "Europe" and not "India" or "Islamic countries" as had been the case before. But Ricci did not stop to simply redefining the scope of the West. He also imported the Ming's geopolitical vocabulary of statehood and applied it to this concept. With this, Ricci did not simply enlarge the scope of the West, but also sought to make it important. Ricci made the West "Great." 